論 文

\title{
Fluoride Ion Conduction of Fluorine Intercalated Graphite $\mathrm{C}_{\boldsymbol{x}} \mathbf{F}$
}

\author{
Shigeaki Suganuma*, Tetsuya Mizu*, Haruo Sakagoshi*, \\ Kunitaka Momota**, Fujio Okino* and Hidekazu Touhara $\dagger^{*}$ \\ (Received August 13, 1993) \\ *Department of Chemistry \\ Faculty of Textile Science and Technology \\ Shinshu University, Ueda 386, Japan \\ **Research and Development Center, Morita Chemicals Co Ltd., \\ Yodogawa-ku, Osaka 532, Japan
}

$\dagger$ To whom correspondence should be addressed.

\begin{abstract}
Fluorine intercalated graphite compounds $\mathrm{C}_{x} \mathrm{~F}$ with ionic or semi-ionic $\mathrm{C}-\mathrm{F}$ bonding were prepared by direct fluorination of $\mathrm{HOPG}$ at $0^{\circ} \mathrm{C}$ or room temperature, and impedance measurements of these materials were carried out. Electrochemical intercalation and deintercalation of fluoride ions into graphite and from $\mathrm{C}_{x} \mathrm{~F}$, respectively, were investigated using acetonitrile solutions containing tetramethyl ammonium fluoride salts. The results indicate that the fluoride ions in the graphite gallery have some mobility, and the electrochemical intercalation and deintercalation of fluoride ions are effected by applied potential gradient. These results suggest that $\mathrm{C}_{x} \mathrm{~F}$ are fluoride ion conducting solid state electrolytes.
\end{abstract}

KEYWORDS; Fluorine intercalated graphite, Fluoride ion conduction, Solid state electrolyte

\section{Introduction}

Fluoride ion conductors have many potential applications in batteries and other electrochemical devices and are of great interest. Crystalline fluoride ion conductor $\beta-\mathrm{PbSnF}_{4}$, which has the highest conductivity known so far at room temperature (RT), exhibits conductivity $10^{-1}-10^{-2} \mathrm{~S} / \mathrm{cm}$ at $200^{\circ} \mathrm{C}^{1)}$. Among the non-crystalline substances, on the other hand, $60 \mathrm{ZrF}_{4} \cdot 32 \mathrm{BaF}_{2} \cdot 8 \mathrm{CsF}$ glass has the fluoride ion conductivity of $c a$. $10^{-5} \mathrm{~S} / \mathrm{cm}$ at $200^{\circ} \mathrm{C}^{2)}$. As for fluoride-graphite intercalation compounds (GICs), although their highly electrical conductivities have been well known ${ }^{3}$, fluoride ion conductivities of the materials have not been known thus far. The fluorine intercalated graphite compounds $\left(\mathrm{C}_{x} \mathrm{~F}\right)$, with ionic or semi-ionic C-F bonds, show excellent properties as a cathode material of lithium battery with anhydrous propylene carbonate (PC)-1M $\mathrm{LiClO}_{4}$ electrolyte solution. Below the current density of $1 \mathrm{~A} / \mathrm{m}^{2}$, these materials show extremely low overpotentials ${ }^{3)-5}$ compared with conventional graphite fluoride cathode $(\mathrm{CF})_{\mathrm{n}}$ or $\left(\mathrm{C}_{2} \mathrm{~F}\right)_{\mathrm{n}}$ with covalent $\mathrm{C}-\mathrm{F}$ bonds. This property indicates that there are some differences in the discharge reaction mechanisms. In the conventional graphite fluorides, the chemical bonds between carbon and fluorine are covalent. The fluorine atoms are strongly bound to the carbon framework and they can not move within the gallery ${ }^{6)}$. The discharge reaction in the conventional graphite fluoride cathodes, therefore, proceeds through the diffusion of 
solvated lithium ions between the layered structure of graphite fluoride. This leads to a high cathode overpotential $^{7)}$. In the case of $C_{x} F$, however, the fluorine atoms are more weakly bound to the carbon framework, and as a result, the diffusion of fluoride ions within the gallery is possible. Accordingly, the discharge reaction seems to consist of the diffusion of fluoride ions from the bulk to the surface of the cathode and the following deintercalation. The present paper reports impedance analysis of $\mathrm{C}_{\boldsymbol{x}} \mathrm{F}$, electrochemical oxidation of graphite and reduction of $\mathrm{C}_{x} \mathrm{~F}$ in the fluoride ion conductive solutions of tetramethyl ammonium fluorides ${ }^{8)}$. Based on the results, the fluoride ion conduction of $\mathrm{C}_{\boldsymbol{x}} \mathrm{F}$ is discussed.

\section{Experimental}

\subsection{Synthesis and Characterization of $\mathrm{C}_{\boldsymbol{x}} \mathrm{F}$}

Highly Oriented Pyrolitic Graphite (HOPG :Union Carbide) as the host graphite was heat-treated for 3 days at $600^{\circ} \mathrm{C}$. Ionic and semi-ionic $C_{x} F$ were prepared by the direct fluorination of HOPG at either $0^{\circ} \mathrm{C}$ or RT for a few weeks. The ionic or semiionic character of $\mathrm{C}-\mathrm{F}$ bonds in $\mathrm{C}_{\boldsymbol{x}} \mathrm{F}$ was investigated by X-ray photoelectron spectroscopy (XPS: Shimadzu ESCA 750 with $\mathrm{Mg}-\mathrm{K} \alpha$ radiation), and the structure of $\mathrm{C}_{\boldsymbol{x}} \mathrm{F}$ was determined by $\mathrm{X}$-ray diffraction analysis (Shimadzu, XD-D1 with $\mathrm{Cu}-\mathrm{K} \alpha$ radiation). The compositions of these materials were determined by gravimetric analysis or XPS analysis.

\subsection{Impedance Measurements}

The impedance measurements were carried out using Yokogawa Hewlett Packard 4194A Impedance/ Gain Phase Analyzer in the frequency range $1 \mathrm{kHz}$ $15 \mathrm{MHz}$ with the oscillation level of $0.5 \mathrm{~V}$ at RT. Since $\mathrm{C}_{\boldsymbol{x}} \mathrm{F}$ is a good electrical conductor, the values of the impedance of $\mathrm{C}_{\boldsymbol{x}} \mathrm{F}$ are usually small and are greatly influenced by the contact noise impedance at the interface between electrode and material. Microelectrodes were employed successfully to investigate the impedance spectroscopy of the $C_{x} F$. Tungsten needles $(\phi=0.06 \mathrm{~mm})$ as the electrode were connected on both edges of the basal planes of $\mathrm{C}_{x} \mathrm{~F}$, and the four-point method was employed (Fig. 1). Ionic and semi-ionic $\mathrm{C}_{\boldsymbol{x}} \mathrm{F}$ samples and pristine HOPG for comparison were analyzed. Equivalent circuits

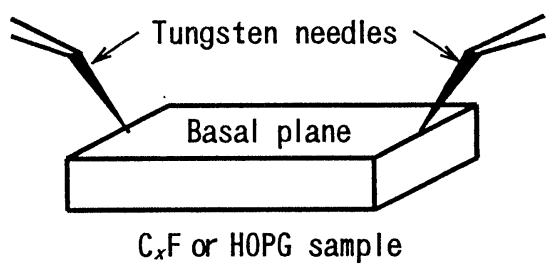

Fig. 1 Electrode for impedance measurement.

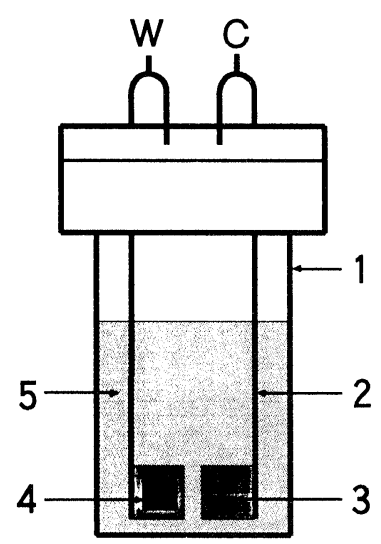

Fig. 2 Cell assembly for electrochemical intercalation and deintercalation of fluoride ions into HOPG and from $\mathrm{C}_{\boldsymbol{x}} \mathrm{F}$, respectively.

$\mathrm{W}$ : working electrode, $\mathrm{C}$ : counter electrode,

1: teflon cell, 2: Pt-wire, 3: Pt-mesh,

4: HOPG or $\mathrm{C}_{x} \mathrm{~F}, 5$ : electrolyte,

were assumed for the obtained impedance spectra Cole-Cole plots, and the optimum values of the components in the circuits were determined so as to reproduce the obtained Cole-Cole plots.

\subsection{Electrochemical Intercalation and Deintercala-} tion of Fluoride Ion

Fig. 2 shows the cell for electrochemical oxidation (intercalation) of HOPG and reduction (deintercalation) of $\mathrm{C}_{\boldsymbol{x}} \mathrm{F}$. Hokuto Denko Potentiostat/ Galvanostat HA-301 was used for galvanostatic electrolysis at current density of $1 \mathrm{~A} / \mathrm{m}^{2}$ (ac-plane area).

In the experiment of the fluoride ion intercalation into the graphite, heat-treated HOPG was wrapped by Pt-mesh and used as the anode, and a Pt-mesh was also used as the counter electrode. 

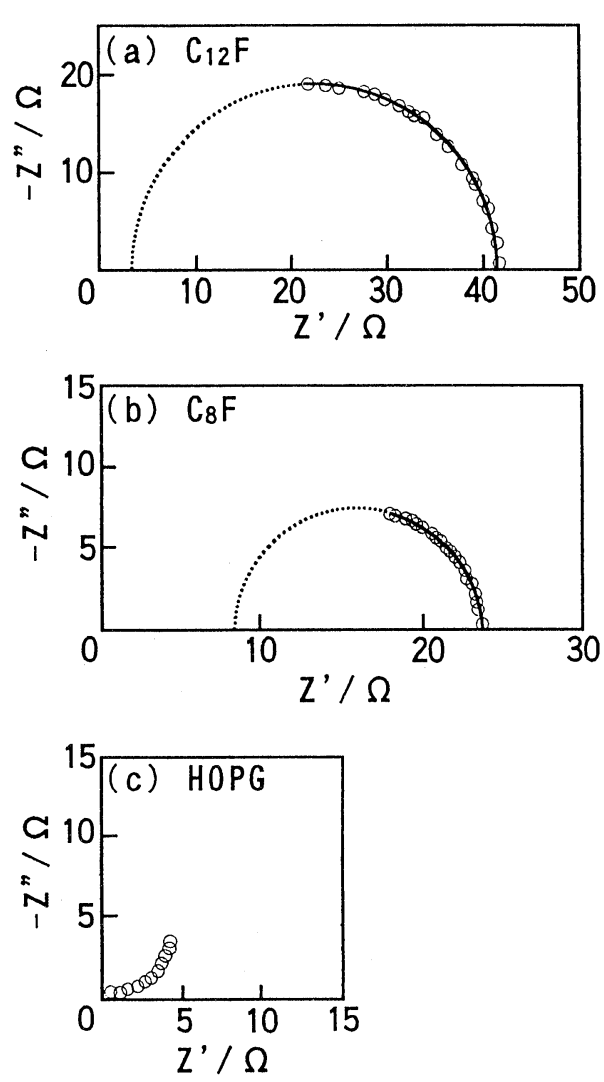

Fig. 3 Complex impedance plots of ionic $\mathrm{C}_{12} \mathrm{~F}(\mathrm{a})$, semi-ionic $\mathrm{C}_{8} \mathrm{~F}(\mathrm{~b})$ and $\mathrm{HOPG}(\mathrm{c})$ in the frequency range of $1 \mathrm{kHz}-15 \mathrm{MHz}$.

The solid curves were obtained based on the equivalent circuit ((a) in Fig. 4) with optimum $R_{1}, R_{2}$ and $C_{1}$ values given in Table 1. The dashed curves were graphical extrapolations of semicircles.

Two kinds of electrolytes were used for electrochemical preparation of $\mathrm{C}_{x} \mathrm{~F}$. One of the electrolytes was $1 M$ solution of $\left(\mathrm{CH}_{3}\right)_{4} \mathrm{NF} \cdot 2 \mathrm{HF}$ (Morita Chemicals) in acetonitrile (Wako Chemicals). The other electrolyte solution was $1 M$ $\left(\mathrm{CH}_{3}\right)_{4} \mathrm{NF} \cdot 4 \mathrm{HF}$-acetonitrile (Morita Chemicals).

In the electrochemical deintercalation of fluoride ion from $\mathrm{C}_{x} \mathrm{~F}$, ionic $\mathrm{C}_{x} \mathrm{~F}$ was used as the cathode in the same way as above and the counter electrode was Pt-mesh. The electrolyte solution used was $1 M$ $\left(\mathrm{CH}_{3}\right)_{4} \mathrm{NF} \cdot 2 \mathrm{HF}$-acetonitrile.

After the electrolysis the samples were washed (a)

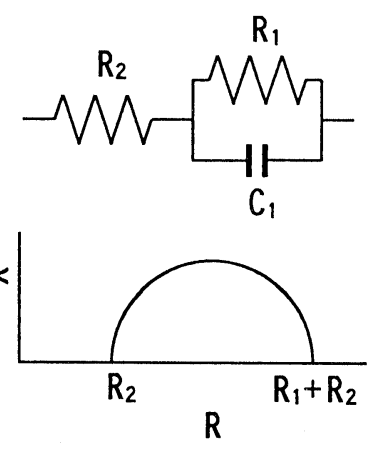

(b)
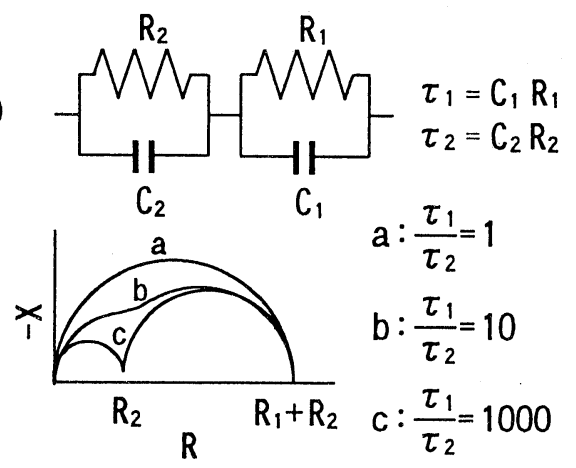

Fig. 4 Equivalent circuits for the impedance plots of $\mathrm{C}_{x} \mathrm{~F}$ shown in Fig. 3.

with acetonitrile to eliminate the residual salt on the surface, and XPS and X-ray diffraction analyses were carried out.

\section{Results and Discussion}

\subsection{Impedance Analysis of $\mathrm{C}_{\boldsymbol{x}} \mathbf{F}$}

In general the bulk impedance of uniform solid electrolyte is equalized by a parallel circuit of the bulk resistance and the geometrical capacitance. The complex impedance plots of such materials have a semicircular shape.

Fig. 3 shows the obtained impedance spectra of ionic $\mathrm{C}_{12} \mathrm{~F}$, semi-ionic $\mathrm{C}_{8} \mathrm{~F}$, and pristine HOPG for comparison. The complex impedance plots of $\mathrm{C}_{x} \mathrm{~F}$ are semicircular. In the case of HOPG, on the other hand, only a limited range of impedance originated from the interface between electrode and HOPG is observed. The equivalent circuit appropriate for these spectra of $\mathrm{C}_{\boldsymbol{x}} \mathrm{F}$ is shown in Fig. 4(a). The optimum values of the components $\left(C_{1}, R_{1}, R_{2}\right)$ in the analogue circuit in Fig. 4(a) are given in Table 1. 
Table 1 Optimum values of components in the equivalent circuit((a) in Fig. 4).

\begin{tabular}{cccc}
\hline & $\mathrm{C}_{1} / \mathrm{F}$ & $\mathrm{R}_{1} / \Omega$ & $\mathrm{R}_{2} / \Omega$ \\
\hline $\mathrm{C}_{22} \mathrm{~F}$ & $2.8 \times 10^{-10}$ & 38.0 & 3.7 \\
$\mathrm{C}_{8} \mathrm{~F}$ & $5.3 \times 10^{-10}$ & 15.4 & 8.4 \\
\hline
\end{tabular}

The frequency simulations based on these values for the circuit were carried out and the results are shown in Fig. 3 by solid lines. The fits were satisfactory indicating the complex impedance plots of $\mathrm{C}_{x} \mathrm{~F}$ can be equalized by this analogue circuit in the experimental frequency range. When the observed plots are assumed to have originated from the bulk impedance of $\mathrm{C}_{x} \mathrm{~F}$, the physical interpretation of the components in the circuit of Fig. $4(a)$ is the following: components $\mathrm{R}_{1}$ and $\mathrm{C}_{1}$, respectively, are the bulk resistance and the geometrical capacitance, and $R_{2}$ is the interfacial charge transfer resistance between electrode and material. In this interpretation, it can be not explained why the observed impedances of $\mathrm{C}_{x} \mathrm{~F}$ are larger than that of HOPG which has lower or the same electron conductivity compared with the $\mathrm{C}_{x} \mathrm{~F}$ used in this experiments.

Another interpretation can be suggested; the observed semicircular plots have originated from the interfacial impedance of electrode and materials. This interpretation leads to the assumption that another semicircle exists at higher frequency range, where the measurement was not carried out in this study. The equivalent circuit, in this case, is shown in Fig. 4(b), and the physical interpretation of the components in this circuit is the following: the parallel made of $R_{1}$ and $C_{1}$, which are the interfacial charge transfer resistance and the electric double-layer capacitance, is the cause of the observed semicircular plots, and components $R_{2}$ and $C_{2}$, respectively, are the bulk resistance and the geometrical capacitance of $\mathrm{C}_{\boldsymbol{x}} \mathrm{F}$. The larger impedance of $\mathrm{C}_{\boldsymbol{x}} \mathrm{F}$ compared to HOPG can be accounted for by the influence of the C-F covalent bonds, which may exist at the surface of the $\mathrm{C}_{\boldsymbol{x}} \mathrm{F}$ materials.

Either of the interpretations suggests that these $\mathrm{C}_{\boldsymbol{x}} \mathrm{F}$ are mixed conduction solid electrolytes of fluoride ion. The fluoride ions in the graphite gallery obtain mobility by potential gradient.

\subsection{Electrochemical Intercalation and Deintercala- tion of Fluoride Ion}

\subsubsection{Electrochemical Intercalation of Fluoride Ion Into Graphite}

Electrochemical syntheses of $\mathrm{C}_{x} \mathrm{~F}$ were attempted using $1 M\left(\mathrm{CH}_{3}\right)_{4} \mathrm{NF} \cdot 2 \mathrm{HF}$-acetonitrile electrolyte. The XPS analysis of HOPG anode after electrochemical oxidations indicated the existence of fluoride ions in the graphite gallery. $\mathrm{X}$-ray diffraction patterns of these materials, however, were not able to be indexed.

On the other hand, in the experiment using $1 M$ $\left(\mathrm{CH}_{3}\right)_{4} \mathrm{NF} \cdot 4 \mathrm{HF}$-acetonitrile electrolyte solution at the current density of $1 \mathrm{~A} / \mathrm{m}^{2}$, the oxidized HOPG gave a clear X-ray diffraction pattern shown in Fig. 5. The pattern indicates that a fluoride-GIC was prepared electrochemically, its stage number being 5 and $d \mathrm{i}$, which is the size of intercalate, $2.7 \AA$. Some of the diffraction lines indicated the existence of higher-stage compounds. The XPS measurements of

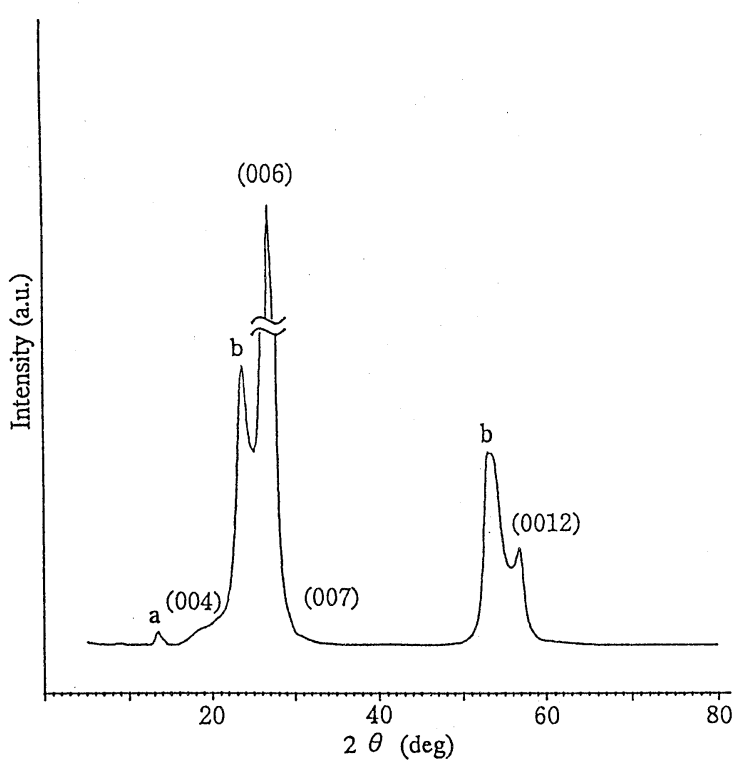

Fig. $5(00 l) \mathrm{X}$-ray diffraction profiles of stage-5 $\mathrm{C}_{18} \mathrm{~F}$ obtained by the electrochemical intercalation in $1 M\left(\mathrm{CH}_{3}\right)_{4} \mathrm{NF} \cdot 4 \mathrm{HF}$-acetonitrile solution. a: the diffraction line of polyvinylchloride film used for the sample protection from moist air, b: higher stage compounds. 


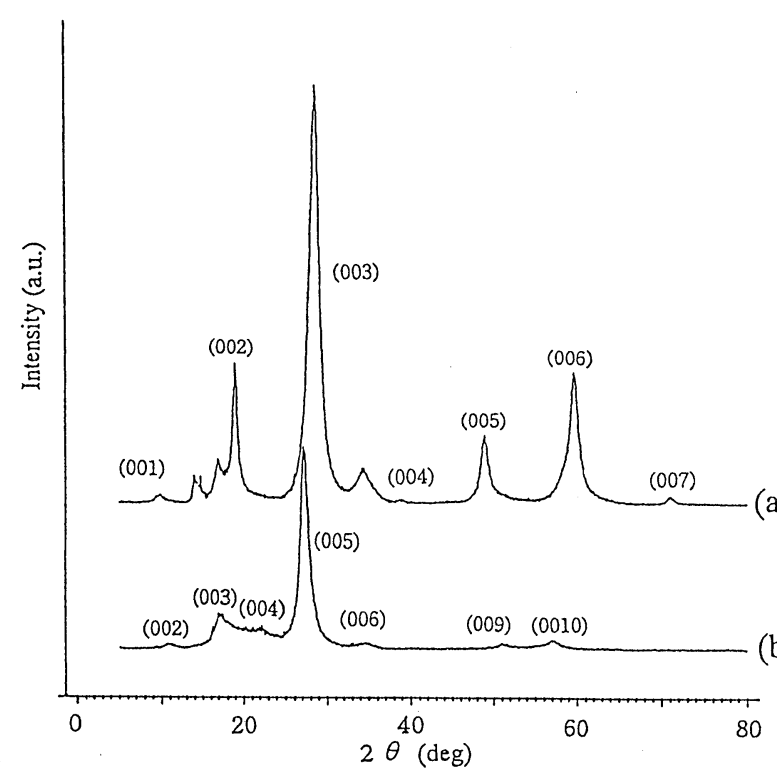

Fig. $6(00 l) \mathrm{X}$-ray diffraction profiles of stage-2 $\mathrm{C}_{5.5} \mathrm{~F}(\mathrm{a})$ prepared by direct fluorination of HOPG and stage- $4 \mathrm{C}_{10} \mathrm{~F}(\mathrm{~b})$ obtained by the electrochemical reduction of $\mathrm{C}_{5.5} \mathrm{~F}$.

the compound show that the bulk C-F bonding nature is ionic, with semi-ionic and covalent bonds at the surface of the material. The composition of prepared material determined by XPS is $\mathrm{C}_{18} \mathrm{~F}$ whereas that from coulometry is $\mathrm{C}_{10} \mathrm{~F}$, indicating the current efficiency of $c a .56 \%$. The open circuit voltage of this electrolysis cell was about $0 \mathrm{~V}$, and the voltage increased to $2 \mathrm{~V}$ as soon as the electrolysis had started. The stepwise potential increase according to the change in stage number, which is reported in the case of electrochemical preparation of sulfate-graphite intercalation compounds ${ }^{9)}$, was not observed in this experiment.

This result suggests that the fluoride ions can be intercalated into the graphite layers electrochemically and the following diffusion of fluoride ions in the graphite gallery occurs. The electrochemical synthesis of $\mathrm{C}_{\chi} \mathrm{F}$ in $50 \%$ aqueous hydrogen fluoride and $1 \mathrm{M}$ NaF-anhydrous $\mathrm{HF}$ solutions have already been reported ${ }^{10)}$. The results of our experiments show that electrochemical synthesis of $\mathrm{C}_{x} \mathrm{~F}$ is also possible in the electrolyte solutions without using $\mathrm{HF}$ solutions. The electrochemical stability and the fluoride ion conductivity of electrolytes ${ }^{11)}$ may influence the electrochemical synthesis of $\mathrm{C}_{\boldsymbol{x}} \mathrm{F}$.

\subsubsection{Electrochemical Deintercalation of Fluoride Ion}

Electrochemical deintercalation of fluoride ions from $\mathrm{C}_{x} \mathrm{~F}$, i.e., electrochemical reduction of the material in $\left(\mathrm{CH}_{3}\right)_{4} \mathrm{NF} \cdot 2 \mathrm{HF}$-acetonitrile solution was performed. The open circuit voltage was about $1.7 \mathrm{~V}$, and the voltage decreased gradually and stabilized at about $-2 \mathrm{~V}$ as the electrochemical reaction proceeded. In this experiment $75 \%$ deintercalation of fluoride ions in the material was achieved. The X-ray diffraction pattern of this material after electrochemical reaction is shown in Fig. 6(b), b) together with that of ionic $\mathrm{C}_{5.5} \mathrm{~F}$ before electrolysis (a). The structural change has occurred through the electrolysis, with the stage number increasing from 2 to 4. The composition of the substance after reduction became $\mathrm{C}_{10} \mathrm{~F}$ by XPS, and the current efficiency was $c a .61 \%$. These results indicate the electrochemical deintercalation of fluoride ions from the graphite gallery of $\mathrm{C}_{\boldsymbol{x}} \mathrm{F}$.

The electrochemical intercalation and deintercalation of fluoride ions into graphite and from $\mathrm{C}_{x} \mathrm{~F}$ involving the change in staging and compositions indicate that graphite and $\mathrm{C}_{x} \mathrm{~F}$ are fluoride ion conductive devices and that the construction of rocking-chair-type secondary battery is possible.

\section{Summary}

The fluoride ions of ionic and semi-ionic $\mathrm{C}_{\boldsymbol{x}} \mathrm{F}$ gain mobility as potential gradient is applied, since they are not bound to carbon atoms in contrast with those in covalent graphite fluorides. Electrochemical intercalation and deintercalation of fluoride ions have been also confirmed. Our present results indicate that ionic and semi-ionic $\mathrm{C}_{x} \mathrm{~F}$ are fluoride ion conducting solid electrolytes.

In the discharge reaction of $\mathrm{C}_{x} \mathrm{~F}$ as a cathode material of the lithium battery, fluoride ion conduction of $\mathrm{C}_{\boldsymbol{x}} \mathrm{F}$ plays $\mathrm{a}$ role in the reaction mechanism, and the polarization character of these batteries differs from the conventional graphite fluoride cathode. 


\section{Acknowledgement}

The authors are indebted to the Ministry of Education, Science and Culture of Japan for financial support by Grant-in-Aid for Scientific Research No. 05650840. We also wish to thank Mr. Y. Takeuchi and Miss. A. Komamura of Shinko Electric Industries Co., Ltd. for their help on impedance measurements. One of the authors (FO) also thanks Research Foundation for Electrotechnology of Chubu for support.

\section{References}

1) J. M. Réau and J. Portier, "Solid Electrolytes, General Principles, Characterization, Materials, Applications," P. Hagenmuller and W. van Gool, Editors, (1978) Ch. 19, Academic Press Inc., New York.

2) Y. Kawamoto and D. Koumyouji, $J$. Electrochem. Soc. 136 (1989) 1816-1819.

3) H. Touhara, S. Suganuma and F. Okino, TANSO
1991 [No.150] 328-337 and references quoted there in.

4) R. Hagiwara, M. Lerner, N. Bartlett and T. Nakajima, J. Electrochem. Soc. 135 (1988) 2393-2394.

5) A. Hamwi, M. Daoud and J. C. Cousseins, Synth. Met. 30 (1989) 23-31.

6) H. Touhara, K. Kadono, Y. Fujii and N. Watanabe, Z. anorg. allg. Chem. 544 (1987) 7-20.

7) H. Touhara, H. Fujimoto and N. Watanabe, Solid State Ionics 14 (1984) 163-170.

8) K. Momota, M. Morita and Y. Matsuda, Electrochim. Acta 38 (1993) 619-624.

9) R. Fujii, Denki Kagaku 40 (1972) 380-384.

10) H. Takenaka, M. Kawaguchi, M. Lerner and N. Bartlett, J. Chem. Soc., Chem. Commun. (1987) 1431-1432.

11) K. Momota, M. Morita and Y. Matsuda, Electrochim. Acta 38 (1993) 1123-1130.

\section{日本学術振興会炭素材料第 117 委員会第 226 回委員会}

1. 日時: 平成 5 年 9 月 24 日(金)

2. 場 所：弘済会館

3. 提出資料:

117-226-A-1 貴金属超微粒子分散炭素の調製とマト リックス炭素の高比表面積化

(九工試)児玉昌也, 本田英昌

117-226-A-2 単結晶 $\mathrm{ZrC}$ の酸化における炭素の析出と 酸化層の微構造観察

(北大·工)嶋田志郎, 西佐古将, 稲垣道夫

117-226-A-3 酸化処理した熱分解黑鉛表面の構造変化 (北大·工)中原雅則, 真田雄三

117-226-A-4 DRIFT/TPD Study of Surface Oxygen Complexes Formed in Carbon Gasification with Oxygen

(Tohoku University) T. Kyotani, Q-. L. Zhuang and A. Tomita

117-226-A-5 フィルム内部からの $\mathrm{N}_{2}$ ガス放出による黒 鉛化ポリイミドフィルムの破裂
(資環研)羽鳥浩章, 山田能生, 白石 稔 117-226-B-1 熱分解カーボンの微細組織のSEM観察 (武蔵工大)吉田 明, 菱山幸宥 117-226-B-2 グラファイトウィスカーのリチウム吸蔵 反応に与える生成プロセスの影響

(大工研)辰巳国昭，Karim Zaghib, 澤田吉裕 (日機装(株)) 阿部浩史, 大崎 孝

117-226-C-1 高炉用コークスの高温における耐熱特性 (茨城大工) 佐藤千之助, 酒井直孝 (豊橋技科大)鈴木隆之 (NKK) 板垣省三，三谷成康

117-226-C-2 Development of self-mending type oxidation protection of furan resin-derived carbon by Ta-compounds addition

(Tokyo Insitute of Technology)

Ei-ichi Yasuda, Sei-Main Park,

Takashi Akatsu and Yasuhiro Tanabe 